\title{
Basil J. Moore's Horizontalists and Verticalists: an appraisal 25 years later
}

\author{
Ulrich Bindseil* \\ Directorate General Market Operations, European Central Bank, Frankfurt, Germany \\ Philipp J. König* \\ Department of Macroeconomics, Economic Policy and Forecasting, German Institute for Economic \\ Research, Berlin, Germany
}

In 1988 Basil Moore published his book Horizontalists and Verticalists: The Macroeconomics of Credit Money, which this year celebrates its 25th birthday. We discuss this book from today's perspective, and in particular whether Moore's main assertions have been validated or rejected by the development of central bank practice and academic monetary economics. We find that the book has impressively stood the test of time and, despite part of textbook economics still insisting on the money multiplier as an explanation for the money supply, it is not much of an exaggeration to say that we have all become 'Horizontalists' in the last 25 years.

Keywords: monetary policy, interest rates

JEL codes: $E 40, E 50$

\section{INTRODUCTION}

A student of neoclassical Austrian Fritz Machlup, Basil Moore became interested in money and banking very early in his career. His thesis dealt with the effects of monetary policy on bank earnings. He spent his first sabbatical with John Gurley and Edward Shaw in Stanford who, in 1960, had written their influential monograph, Money in a Theory of Finance. In 1968, Moore himself published his first book, An Introduction to the Theory of Finance (Hein and Nichoij 2010). As we point out below, we believe that it is, among other things, his deep interest in and firm knowledge of finance and banking issues that enabled Moore to develop what he later called the 'horizontalist view of credit money'. Under the influence of Paul Davidson, Moore began to develop his views on monetary macroeconomics, primarily as a response to the dominant paradigm of Friedman's monetarism. This culminated in 1988 in his book, Horizontalists and Verticalists: The Macroeconomics of Credit Money, which this year celebrates its 25th birthday. We discuss this book from today's perspective, and in particular whether Moore's main assertions have been validated or rejected by the development of central bank practices

* The views in this article are those of the authors and do not necessarily reflect those of their respective affiliations. 
and academic monetary economics. We find that the book has impressively stood the test of time and, despite part of textbook economics still insisting on the money multiplier as an explanation for the money supply, it is not much of an exaggeration to say that we have all become 'Horizontalists' in the last 25 years.

\section{2 'VERTICAL' VS 'HORIZONTAL' VIEWPOINTS}

The 'verticalist' view states that the money supply function is exogenous, is independent from money demand, and can, at least to a reasonable extent, be controlled by the central bank. The verticalist paradigm may apply in a world of commodity or pure fiat money. But, as Moore argued in 1988, it does not provide a correct description of a credit economy. Rather, in such a world, a 'horizontalist' view must be adopted. The supply of credit money is endogenous, is demand-determined, and only its price can be controlled by the central bank, not its quantity.

This was Moore's message in 1988 and it was a brave one. It postulated nothing less than the failure of a key assumption taken for granted by almost every monetary macroeconomist in the twentieth century: that the central bank can control the monetary base and thereby exert control over the stock of money supplied to the economy.

Moore was aware of the consequences of removing this central assumption and instead adopting the horizontal view. He did not shy away from explicitly spelling this out:

The 'Horizontalist' notion ... implies, for example, that the entire literature on monetary control and on monetary policy, IS-LM analysis, the Keynesian and the money multiplier, liquidity preference, interest rate determination, the influence of public sector deficits on the level of domestic interest rates, growth theory, and even the theory of inflation must be comprehensively reconsidered and rewritten. (Moore 1988, p. xiv)

And he added self-confidently:

Virtually everything written in the monetary, macro- and growth literature - [is] either misspecified or incomplete. Such fundamental theoretical misspecification renders all accompanying empirical parameter estimates highly suspect. (ibid., p. xiv)

By providing the analytical and empirical foundation of the horizontalist view, Moore aimed at fundamentally reshaping monetary economics.

\section{HOW SUCCESSFUL HAS MOORE BEEN?}

Moore's ideas may have shaped the course of post-Keynesian economics. Although we have to admit that neither of us is much acquainted with the post-Keynesian literature, we believe that the Festschrift edited by Setterfield (2006) is evidence enough of Moore's influence in this field of economics.

However, mainstream monetary economics has largely ignored 'Horizontalists and Verticalists,' even though Niggle (1989) stressed that the book should have been 'as influential within monetary economy and political economy as Keynes's Tract on Monetary Reform, Treatise on Money, and General Theory' (p. 1181). We too do believe that Moore's book rightly deserves its place in the history of economic thought. But we believe that this will take until mainstream (and in particular textbook) economics has freed itself completely from the assumption of an exogenous and controllable money stock that Moore identified to be so mistaken. 
The year 1988, in which Moore wrote, was, however, not ripe for his view. It was a time when mainstream monetary economics had already experienced fundamental changes that continue until today. Robert Lucas had issued his critique on econometric policy evaluation 12 years earlier and thereby triggered the avalanche of micro-based macroeconomics that still prevails today. The foundations for modern New Keynesian monetary models had been laid by Calvo (1983) or Blanchard and Kyotaki (1987). The movement of rational expectations economics was already in full swing. All these developments took place without taking note of the 'horizontalist' view. With respect to monetary issues, they firmly rested on the possibility that central banks can exert direct control over the monetary base. For example, the indeterminacy debate, triggered by Sargent and Wallace's (1981) unpleasant monetarist arithmetic - whose repercussions run through virtually all current monetary models - essentially focused on the question of whether or not the price level could be determined by means of the interest rate or whether it could only be determined by setting the money stock. In a similar vein, the instrument-choice problem stressed in the influential model by Poole (1970) discussed the pros and cons of using the interest rate or the money supply to stabilize macroeconomic fluctuations. Moore rightly criticizes this highly popular approach as 'superficially reasonable ecclecticism' (Moore 1988, p. 80) and as 'simply incorrect' (ibid., p. 92).

Among Moore's few allies during the 1980s was Charles Goodhart, who 'endorse[d] with wholehearted enthusiasm the greater part of [Moore's] theme' (1989a, p. 29), and whom Moore referred to as his 'favorite real-world central banker' (Moore 1988, p. xix).

In particular, Moore and Goodhart shared the view that 'the use of the money multiplier ... obscures the underlying process of monetary determination' (Goodhart 1984, quoted from Moore 1988, p. 70), that '[t]here is no a priori reason to believe that the authorities' intention is generally to control this variable; it may be endogenously determined' (Goodhart 1989b, p. 137); and 'that the crucial error of the multiplier approach is that it mistakenly assumes ... that the central bank has the ability to increase or reduce the quantity of the base at its discretion (Moore 1988, p. 82).

In our opinion, these criticisms were at the core of Moore's reasoning. For if the monetary base is endogenous and not under the control of the central bank, then the whole process of credit creation must be endogenous as well. Hence, the whole idea of monetary control must collapse once the base becomes endogenous, and this paves the way for the alternative 'horizontal' view.

The mere fact that almost any best-selling intermediate textbook - for example Ball (2010), Mankiw (2003), or Mishkin (2009) - still explains the money supply by means of the multiplier process and proceeds under the assumption that the central bank 'controls the supply of money by increasing or decreasing the number of dollars in circulation through open-market operations' (Mankiw 2003, p. 482) reveals that Moore's self-imposed goal - unmistakably set out at the beginning of his book in a quote from Keynes - to escape from the old ideas which ramified into every corner of economists' minds, has unfortunately not yet been reached.

But Moore's goal gradually comes closer. Because, if anything, the last 25 years have vindicated the substance of his thinking in a surprising way that could hardly have been anticipated in 1988. Central bankers have by now largely buried 'verticalism', at least when it comes to monetary policy implementation - that is, the choice and technique to achieve the operational target of monetary policy. And even though the textbook and academic mainstream view on the money supply still largely maintains that the central bank can control it, the real-world developments in monetary policy practice have 
paved the way for an understanding of monetary policy as interest rate policies that must necessarily sooner or later result in the horizontalist view of Moore.

Scrutinizing the Fed's operating procedures of previous decades, Moore (1988, p. 100) had already reached the rather crushing conclusion that money supply targeting was an 'exercise in illusions.' He devotes particular attention to the Fed's practices after the Volcker money control experiment of 1979-1982, and while noting that actually the Fed had already returned in the mid 1980s to something close to 'dirty' interest rate control, he explains that the

[c]entral banks are reluctant to acknowledge their interest rate procedures and policy targets publicly, mainly for political reasons ... Higher interest rates, since they increase borrowing costs and reduce private wealth values, are always politically very unpopular. ... The great virtue of 'intermediate monetary targeting', with its high rhetoric of 'reserve restraint', is that it enables the Fed to shed all visible responsibility for interest rates, which it effectively continues to control directly within a narrow range. No one appears responsible. 'Deniability' is valued by all political actors. (ibid., p. 137)

Even if not admitted at the time of Moore's book, the 1983-1990 period of borrowed reserves appears from today's perspective clearly as an attempt of the Fed to retreat from the reserve position doctrine. It is remarkable that the Fed never tried to openly justify borrowed reserves targeting as a coherent method. In 1994, just 6 years after Moore's book was published, the gradual move to federal funds rate targeting was completed and the Fed today announces, after each Federal Open Market Committee (FOMC) meeting, its decision with regard to the fed funds target rate (as we have known it ever since). In 1998, for the first time, the 'Domestic Policy Directive,' which is part of the minutes of the FOMC, contains a reference to the fed funds target rate, instead of a reference to the rather vague concept of 'reserve pressure.' For instance, the domestic policy directive in effect on 1 January 1997 still contained the formula: 'in the implementation of policy for the immediate future, the Committee seeks to maintain the existing degree of pressure on reserve position,' while the one in effect on 1 January 1998 reads, for the first time in the Fed's history, 'in the implementation of policy for the immediate future, the Committee seeks conditions in reserve markets consisting with maintaining the federal funds rate at an average of around $5.5 \%$.' Moreover, still in 1998, contemporaneous reserve accounting was substituted again by lagged reserves accounting, which facilitates the operating procedures of both the Fed and its counterparties. This is further proof of the fact that the influence of the monetarist viewpoint is constantly diminishing among practitioners (contemporaneous reserve accounting had been advocated by Milton Friedman as a key element of quantity oriented monetary policy implementation since 1960). Under lagged reserve accounting, both the Fed and the banks now know the level of required reserves before the start of the reserve maintenance period. Finally, in 2003, the Fed implemented a reform to its discount window, setting the discount rate systematically 100 basis points above the federal funds target rate and thus, after more than 80 years, it put an end to setting the discount rate below market rates.

And, surprisingly, it's all contained in Basil Moore's book. More than 2 decades before Friedman and Kuttner (2010) explained to the inclined reader of the Handbook of Monetary Economics how central banks do it - that is, steering the rates Moore nailed it down in chapter 5 of his book. It is remarkable that a book that must have appeared rather provocative when it was published has been corroborated so unambiguously by actual developments in policymaking within such a short period of time. 
What may explain why Moore could formulate his critique of the US Federal Reserve and academic monetary doctrine so early was his strong interest in banking and finance matters. Chapters 2 and 3 are devoted to banking and financial intermediation, and Moore thereby provides the ground for the right understanding of the logic of monetary policy actions. It is even more remarkable that he warns already in 1988 against the increasing liquidity and financial stability risk relating to the issuance of short-term debt instruments by banks. These worries were largely confirmed by the developments that led to the financial crisis of 2007-2009 and the need for central banks to massively intervene to substitute for the drying-out of short-term capital market funding sources.

\section{THE DECLINING INFLUENCE OF 'VERTICALISM'}

Although no explicit reference is usually made to 'horizontalism' and even though most academics would still not freely admit that the money supply is endogenous, the decreasing influence of 'verticalism' in monetary economics can also be measured by the increasing number of mainstream authors who acknowledge real-world practice and therefore embrace the idea of central banks controlling interest rates and not quantities, and who consider it (again) natural to either model monetary policy implementation as a steering of interest rates (for example Hamilton 1996, followed by many others), or to incorporate in macroeconomic models the assumption that the transmission mechanism starts with the central bank's steering of short-term interest rates (for example Taylor 1993; Clarida et al. 1999; Woodford 2003).

The last major monograph on monetary theory, Woodford (2003) is already fully aligned with Moore's observations from 15 years earlier. ${ }^{1}$ As Woodford notes:

Monetary policy decision making almost everywhere means a decision about the operating target for an overnight interest rate, and the increased transparency about policy in recent years has almost meant greater explicitness about the central bank's interest-rate target and about the way in which its interest-rate decisions are made. ... Nonetheless, theoretical analyses of monetary policy have until recently almost invariably characterised policy in terms of a path for the money supply, and discussions of policy rules in the theoretical literature have mainly considered money-growth rules of one type or another. This curious disjunction between theory and practice predates the enthusiasm of the 1970s for monetary targets. (Woodford 2003, ch. 1, p. 30)

It is, however, hard to understand why an oeuvre that has been corroborated so well by reality has not yet received its well-deserved recognition. For us, the only plausible explanation may be that Moore's message is formulated so vigorously that it still appears overly provoking to many. Since Cassel (1928), no one (except for Charles Goodhart maybe) has dared to question the 'verticalist' orthodoxy in such an open way.

Yet, in light of the strong vindication of Moore's book and the recent progress of mainstream economics to formulate monetary policy in terms of interest rates, we

1. One of us (UB) has to acknowledge that he himself largely overlooked Moore, in Bindseil 2004a and 2004b. In Bindseil 2004a (p. 33), a reference is made to Moore (1988), but the author has to admit that he had not read Moore's book at that time and certainly overlooked the extent to which it had already made many points articulated independently in Bindseil 2004a and $2004 \mathrm{~b}$ more than 15 years later (which had less merit as the changes described above had already taken place). 
believe that the textbook view of controllable money supply will also be buried some day and thus the mainstream academic profession must, hopefully, eventually recognize the merits and power of the horizontalist view.

\section{MOORE IS RIGHT, BUT...}

While we fully accord with Moore's main themes, there are three of his arguments that we would not fully subscribe to:

1. The Wicksellian theory of the natural rate of interest has regained popularity and we believe that this theory is fundamentally correct, even if there is a danger of misinterpreting it. In our view, Moore interpreted Wicksell too narrowly, by inferring from Wicksell's natural rate hypothesis that: (i) money rates are not controlled by the central bank; (ii) money rates will over time converge again to the real rate, and are, in this sense, endogenous; and (iii) the relevance of disequilibrium is played down by Wicksell. In contrast, we believe that the idea of a natural rate of interest does not put into question the possibility that the central bank controls the actual money rate. Given the central bank's control over the money rate, there is no natural convergence process of the actual money rate to the real rate. As revealed for instance by the German hyperinflation, a central bank can maintain the money rate at too low a level for many years. Obviously this policy parameter does not have a natural tendency to correct itself.

2. Moore's book is somewhat US-centric, and in our view it does not pay enough attention to the fact that 'horizontalism' was the leading doctrine in Europe (and all over the world) before 1914 - that is, before the Fed was created and invented verticalism around 1920. In fact, Bagehot (1873) was an downright 'horizontalist,' and the discount facility-based monetary policy implementation that was common practice by all central banks in Europe before 1914 can be seen as a clear-cut reflection of a 'horizontalist' approach to monetary policy.

One of the reasons why Moore may have devoted relatively little attention to the nineteenth century is his correct remark that commodity money is not the same as credit money, and that David Hume's quantity theory was indeed appropriate as a theory for a commodity standard. However, this should, in our view, not preclude one from learning from nineteenth-century monetary policy implementation techniques. Even though the economies operated largely under commodity standards, they also relied on a significant credit expansion by commercial banks, and the backing by metal was seldom complete. As is illustrated by the writings of Thornton (1802 [1962]), Bagehot (1873) or King (1936), 'verticalism' would not have been a feasible option in the predominant nineteenth-century currency standard.

3. As a last side remark, Moore associates the representation of the central bank and the banking system in T-accounts with monetary base targeting and the money multiplier doctrine, and therefore rejects its usefulness. We came to the conclusion that T-account modeling of monetary and financial transactions is indeed an excellent way to represent monetary policy implementation under any setting, and certainly also in a horizontalist one. The recent writings of, for example, Godley and Lavoie (2007) confirm this point of view. Since the control of interest rates takes place through financial transactions which have a balance sheet representation, it provides discipline to explicitly write down these transactions and how they feed 
through the financial system in a closed system of T-accounts. We develop this approach for example in Bindseil and König (2011; 2012), and Bindseil and Winkler (2012).

\section{CONCLUSION}

Twenty-five years ago, Basil Moore did a remarkable job in refuting the leading doctrines of 'verticalism' and monetary targeting. The developments since then have corroborated his theory and his views in a remarkable way.

The heritage left by his book, the intellectual deepness of his thoughts, and the clarity with which his ideas were put forward have, in our view, made Horizontalists and Verticalists a key contribution to monetary economics. This book has stood the test of time and is still a must-read for anyone interested in understanding the functioning of the monetary system and the relationship between the banking and financial sector and the central bank.

\section{REFERENCES}

Bagehot, W. (1873), Lombard Street - A Description of the Money Market, Homewood, IL: Richard D. Irwin.

Ball, L. (2010), Money, Banking and Financial Markets, New York: Worth Publishers.

Bindseil, U. (2004a), Monetary Policy Implementation, Oxford: Oxford University Press.

Bindseil, U. (2004b), 'The Operational Target of Monetary Policy and the Rise and Fall of Reserve Position Doctrine,' ECB working paper No. 372.

Bindseil, U. and P. König (2011), 'The Economics of Target2 balances,' SFB 649 Discussion Paper 2011-035, Humboldt-Universität zu Berlin.

Bindseil, U. and P. König (2012), 'Target2 and the European Sovereign Debt Crisis,' Kredit und Kapital, 45(2), 135-174.

Bindseil, U. and A. Winkler (2012), 'Dual Liquidity Crises under Alternative Monetary Frameworks - a Financial Accounts Perspective,' ECB Working Paper Series, No. 1478.

Blanchard, O. and N. Kyotaki (1987), 'Monopolistic Competition and the Effects of Aggregate Demand,' American Economic Review, 77(4), 647-666.

Calvo, G. (1983), 'Staggered Prices in a Utility-Maximizing Framework,' Journal of Monetary Economics, 12, 383-398.

Cassel, G. (1928), 'The Rate of Interest, the Bank Rate, and the Stabilisation of Prices,' Quarterly Journal of Economics, 42, 511-529.

Clarida, R., J. Galí, and M. Gertler (1999), 'The Science of Monetary Policy: a New Keynesian Perspective,' Journal of Economic Literature, 37, 1661-1707.

Friedman, B. and K. Kuttner (2010), 'Implementation of Monetary Policy: How Do Central Banks Set Interest Rates?', in B. Friedman and M. Woodford (eds), Handbook of Monetary Economics, Vol. 3, Amsterdam: North-Holland, pp. 1345-1438.

Godley, W. and M. Lavoie (2007), Monetary Economics: an Integrated Approach to Credit, Money, Income, Production and Wealth, New York: Palgrave Macmillan.

Goodhart, C.A.E. (1984), Monetary Theory and Practice, London: Macmillan.

Goodhart, C.A.E. (1989a), 'Has Moore Become Too Horizontal?', Journal of Post Keynesian Economics, 12(1), 29-34.

Goodhart, C.A.E. (1989b), Money Information and Uncertainty, Cambridge, MA: MIT Press.

Hamilton, J.D. (1996), 'The Daily Market for Federal Funds,' Journal of Political Economy, 104, 26-56.

Hein, E. and T. Nichoij (2010), 'Interview with Basil Moore,' Intervention: European Journal of Economics and Economic Policies, 7(1), 7-11. 
390 Review of Keynesian Economics, Vol. 1 No. 4

King, W.T.C. (1936), History of the London Discount Market, London: Frank Cass.

Mankiw, G. (2003), Macroeconomics, New York: Worth Publishers.

Mishkin, F. (2009), Economics of Money, Banking and Financial Markets, New Jersey: Prentice Hall.

Moore, Basil (1988), Horizontalists and Verticalists: The Macroeconomics of Credit Money, Cambridge, UK: Cambridge University Press.

Niggle, C. (1989), 'Horizontalists and Verticalists - Review,' Journal of Economic Issues, 23(4), $1181-1185$.

Poole, W. (1970), 'Optimal Choice of Monetary Policy Instruments in a Simple Stochastic Macro Model,' Quarterly Journal of Economics, 84, 197-216.

Sargent, T. and N. Wallace (1981), 'Some Unpleasant Monetarist Arithmetic,' Quarterly Review, Federal Reserve Bank of Minneapolis, Fall.

Setterfield, M. (2006), Complexity, Endogenous Money, and Macroeconomic Theory: Festschrift in Honor of Basil J. Moore, Cheltenham, UK and Northampton, MA: Edward Elgar.

Taylor, John B. (1993), 'Discretion versus policy rules in practice,' Carnegie-Rochester Conference Series on Public Policy, 39, 195-214.

Thornton, H. (1802 [1962]), An Inquiry into the Nature and Effects of Paper Credit of Great Britain, New York: Kelley.

Woodford, M. (2003), Interest and Prices: Foundations of a Theory of Monetary Policy, Princeton, NJ: Princeton University Press. 